Wilfrid Laurier University

Scholars Commons @ Laurier

$5-1-1984$

\title{
Evaluating Human Rights in Africa: Some Problems of Implicit Comparisons
}

Rhoda E. Howard-Hassmann

Wilfrid Laurier University, hassmann@wlu.ca

Follow this and additional works at: https://scholars.wlu.ca/poli_faculty

\section{Recommended Citation}

Howard-Hassmann, Rhoda E., "Evaluating Human Rights in Africa: Some Problems of Implicit Comparisons" (1984). Political Science Faculty Publications. 18.

https://scholars.wlu.ca/poli_faculty/18

This Article is brought to you for free and open access by the Political Science at Scholars Commons @ Laurier. It has been accepted for inclusion in Political Science Faculty Publications by an authorized administrator of Scholars Commons@ @aurier. For more information, please contact scholarscommons@wlu.ca. 


\title{
HUMAN RIGHTS QUARTERLY
}

\section{Evaluating Human Rights in Africa: Some Problems of Implicit Comparisons}

\author{
Rhoda Howard
}

Since the 1970s, many humanistically minded academics have become concerned with the comparative measurement and analysis of human rights. The new concern is partly a result of the introduction of human rights as a subject of United Nations debates and foreign policy deliberations, especially in the United States during the Carter Administration (1977-81). Frequently, on the intergovernmental and national levels, the debate is nothing more than a new means of rhetoric, with an additional patina of moral concern, for asserting a nation-state's normal national security interests.

In the United Nations and other such fora, a favorite tactic of debate is to compare one's own country's human rights strengths with another country's human rights weaknesses. Thus socialist countries criticize the lack of welfare security in capitalist countries, while the latter reply with an indictment of the lack of civil liberties in the former. Former imperialist powers criticize the human rights practices of their former colonies. Developed countries and underdeveloped countries are also compared, almost inevitably to the latters' disadvantage. Finally, since no country has completely lived up to the United Nations ideal as embodied in the International Bill of Rights, ${ }^{1}$ it is fair game for adversaries to hold up that ideal as a mirror to reflect human rights abuses.

In this paper, I illustrate the problems of how implicit human rights comparisons affect one's evaluations of human rights performance, by discussing

1. The International Bill of Human Rights comprises three sets of standards. Universal Declaration of Human Rights, adopted 10 December 1948; G.A. Res. 217 A (III), U.N. Doc. A/810 (1948). International Covenant on Economic, Social and Cultural Rights, opened for signature 19 December 1966, entered into force 3 January 1976; G.A. Res. 2200 A (XXI), 21 U.N. GAOR Supp. No. 16, at 49, U.N. Doc. A/6316 (1966). International Covenant on Civil and Political Rights, opened for signature 19 December 1966, entered into force 23 March 1976; G.A. Res. 2200 A (XXI), 21 U.N. GAOR Supp. No. 16, at 52, U.N. Doc. A/6316 (1966). 
the kinds of comparisons to which Africa is often subject. I refer for factual examples to a select group of sub-Saharan African countries, namely, Gambia, Sierra Leone, Ghana, Nigeria, Kenya, Malawi, Tanzania, Uganda, and Zambia - all (presently or formerly) English-speaking countries, colonized by the United Kingdom, which obtained their independence in the early 1960 s. In the course of my research ${ }^{2}$ on human rights in these countries, I have become aware that my evaluation of their performance depends partly on my implicit comparisons with performance in other times and places. If I judge the nine countries against the human rights ideal as expressed in the International Bill of Rights, they fare quite poorly. They fare quite poorly also if I compare them with developed Western democracies or with their "mother country," Britain, in the contemporary period. But if I compare them with the now-developed world as it was two or three hundred years ago, i.e., at a similar "state" of economic development and nation-building, they fare much better. If I compare them with themselves under the colonial period, they also fare quite well. If I compare them with themselves in their own political-cultural past (in the precolonial period), the evaluation is mixed.

One needs, then, to be aware of the comparisons one is making. All evaluations of human rights in specific nation-states contain implicit comparisons, either with some philosophical and judicial ideal or with human rights in selected other nation-states. Comparisons are useful: they can help to measure realizations as well as abuses of human rights and to come up with realistic assessments of what is possible and probable. An historical sense will facilitate measurement of past progress and will make predictions possible. Social or cultural comparisons will facilitate a sense of how needs, wants, and rights are reinterpreted as societies change; such comparisons will also remove the stress from ethnic or regional peculiarities (e.g., "African" versus "Western") and instead stress similarities and differences of social organization.

I illustrate below how one's implicit evaluations of human rights in English-speaking sub-Saharan Africa can change, depending on the comparison one makes.

\section{COMPARING HUMAN RIGHTS IN AFRICA WITH THE IDEAL}

The internationally recognized ideal of human rights is the International Bill of Rights, a package of rights which has been progressively defined by the United Nations since 1948. As is well known, the two 1966 Covenants pro-

2. See Rhoda Howard, "The Dilemma of Human Rights in Sub-Saharan Africa," International Journal 35 (Autumn 1980), 724-747, and other references below. 
vide the basic list of rights in the international human rights package, although a number of supplementary instruments elaborate specific rights. ${ }^{3}$

The criticisms of the practice of deriving human rights ideals from United Nations standards are well-known. First, United Nations practice in enumerating lists of rights is hardly that of an independent, unbiased body of thinkers. The United Nations is a political body which is not universal, even in 1983, in its membership. At the time the Universal Declaration was formulated, the Third World carried considerably less influence within the organization than it does today. The two Covenants derived from the Declaration were products of the Cold War era; thus, especially at the urgings of the United States (which has yet to ratify either Covenant), so-called civil and political rights were split off from so-called economic, social, and cultural rights. ${ }^{4}$ Aside from these obvious political biases, United Nations practice can result in selective international condemnation of some regimes, e.g., South Africa, but nary a slap on the hand for others, e.g., Amin's Uganda. ${ }^{5}$

These biases in the formulation of ideals are reflected in the actual content of the Covenants. Africans frequently draw attention to the imbalance between expecting immediate implementation of civil and political rights (Civil-Political Covenant, Article 3), but only gradual implementation of economic, social, and cultural rights (Economic-Social-Cultural Covenant, Article 2(1)). Surely, many Africans argue, the latter rights should take priority over the former in their poverty-stricken, underdeveloped countries. ${ }^{6}$ The huge list of rights in the two covenants is also criticized: even within the two categories the lists contain no priorities (other than the distinction between those rights that are derogable in times of officially declared national emergencies and those that are not [Civil-Political Covenant, Article 4]). Hence the new interest in discussing both basic needs as an economic strategy ${ }^{7}$ and basic rights as a political strategy. Should, for example, the country which (without a national emergency) violates Article 25(b) of the

3. See generally Richard B. Lillich, International Human Rights Instruments (Buffalo, N.Y.: William S. Hein Co., 1983).

4. Henry Shue, Basic Rights: Subsistence, Affluence, and U.S. Foreign Policy (Princeton: Princeton University Press, 1980), 6.

5. On the double standard with regard to violations of human rights in Africa, see Warren Weinstein, "Africa's Approach to Human Rights at the United Nations," Issue 6 (Winter 1976), 14-21, and A. Glenn Mower, Jr., "Human Rights in Black Africa: A Double Standard?" Human Rights Journal 9 (January-March 1976), 39-70.

6. For an eloquent statement on civil-political versus economic rights, see Julius K. Nyerere, "Stability and Change in Africa" (an address at the University of Toronto, 1969), reprinted in Colin Legum, ed., Africa Contemporary Record (London: Rex Collings), vol. 2 (1969-70), C30-31.

7. The World Bank is particularly interested in the basic-needs approach to development, as numerous articles, especially in World Development, attest. See, e.g., Paul Streeten, "Basic Needs and Human Rights," World Development 8 (1980), 107-111, and Shahid Javed Burki and Mahbub UI Haq, "Meeting Basic Needs: An Overview," World Development 9 (1981), 167-182. 
Civil-Political Covenant, regarding "genuine periodic elections," be criticized as severely as the country which violates Article 7, regarding the right not to be tortured? Should the right to work under Article 6 of the Economic-SocialCultural Covenant be as important as the right to eat under Article 11?

Yet it is somewhat specious to continue making the above criticisms of biases in human rights standards in the 1980s; for in the 1970s, the Third World members of the U.N. made a concerted effort to rectify the perceived bias toward political, as against economic, rights. The effort was successful, indeed perhaps too successful, as there is now a general trend to assert that political rights and civil liberties must wait until economic rights have been realized. ${ }^{8}$ This trend can be seen most clearly in the calls for a New International Economic Order (N.I.E.O.) beginning in 1974. ${ }^{9}$ The most important of the numerous documents agreed upon since 1974 was a 1977 U.N. resolution, "Alternative approaches and ways and means within the United Nations system for improving the effective enjoyment of human rights and fundamental freedoms." 10 This resolution stated that equal attention ought to be given to civil-political and economic-social-cultural rights. ${ }^{11}$ It then went on, however, to say that in the U.N. system, priority with regard to human rights ought to be given to questions of national sovereignty ${ }^{12}$ and to the realization of the N.I.E.O. ${ }^{13}$ It further requested the U.N. Commission on Human Rights to accept these priorities, presumably over its other concerns. Thus the U.N. system was deflected from investigating individual human rights in the civil and political sphere: the cynic might perhaps conclude that Third World elites, by refocusing U.N. standard-setting activities onto the realm of international inequalities, had preserved their own opportunities for internal inequalities and denial of political rights.

Some Africans might well counter such a cynical interpretation by pointing out that there is, in their view, another inherent bias in the U.N. human rights ideals, that of stressing individual over group rights. This criticism is both political and cultural. Politically, it is based on the view that over the last five centuries, the most immense, systematic, and brutal violations of human rights in Africa have been those of the international slave trade, colonialism, and apartheid. Insofar as apartheid still exists and insofar as colonialism is perpetuated by allegedly neocolonial economic strategies, then in the

8. For my own views on this subject, see Rhoda Howard, "The Full-Belly Thesis: Should Economic Rights Take Priority over Civil and Political Rights? Evidence from Sub-Saharan Africa," Human Rights Quarterly 5 (November 1983), 467-490.

9. U.N. General Assembly, "Declaration on the Establishment of a New International Economic Order," Resolution 3201 (S-VI) of 1 May 1974 (General Assembly, 6th Special Session), in U.N., Resolutions 14 (1972-74), 527-529.

10. U.N. General Assembly, Resolution 32/130 (1977), in U.N., Resolutions and Decisions (20 September-21 December 1977), Supp. 45, at 150-151.

11. Ibid., art. 1(a).

12. Ibid., art. 1(e).

13. Ibid., art. $1(f)$. 
African view the onus for rectifying human rights abuses in Africa lies especially on the Western, developed world to compensate for past and present injustices and inequalities. Culturally, the argument is that Africans are not individualists, that they are much more group- or communityoriented than Westerners. Thus, Africans maintain, much of the CivilPolitical Covenant ought not to apply to them.

This African criticism of the U.N. ideal is now embodied in the 1981 African Charter of Human and Peoples' Rights. ${ }^{14}$ The addition of peoples' rights, even in the very title of this African Charter, marks it off from all other regional charters of rights, such as the European and American Conventions. ${ }^{15}$ If the African Charter is taken as the new, relevant ideal to which practice in individual African states must adhere, then the African human rights record will be substantially better than if it is compared with the U.N. ideal.

There have been, for example, some severe ethnic persecutions in independent English-speaking sub-Saharan Africa. These include Idi Amin's appalling slaughter of specific ethnic groups such as the Acholi and the Langi ${ }^{16}$ and the Kenyan persecution of ethnic Somalis in the 1960s. ${ }^{17}$ But, overall, the cultural integrity of minority ethnic groups has been subject to far less attack than one might expect of new nation-states, even in cases of secessionism (the Igbo of Nigeria) or irredentism (the Ewe of Ghana ${ }^{18}$ ). This does not mean that such groups have suffered no prejudice or discrimination. The Nigerian civil war began after up to fifty thousand Igbo (Biafrans) were slaughtered in the north in 1966. After the Biafran secessionists were defeated in 1970, the Igbo were rapidly reintegrated into national life; but they still suffer discrimination both from their former enemies and from inhabitants of minority (non-Igbo) areas of eastern Nigeria. ${ }^{19}$ There is no

14. African Charter on Human and Peoples' Rights, adopted by the O.A.U. Summit at Nairobi, Kenya, 27 June 1981; O.A.U. Doc. CAB/LEG/67/3, rev. 5; reprinted in International Legal Materials 21 (1982), 58. [Editor's note: see B. Obinna Okere, "The Protection of Human Rights in Africa and the African Charter on Human and Peoples' Rights," Human Rights Quarterly, this issue.]

15. For an analysis of the African Charter and comparison with other regional charters, see Okere, note 14 above, and Richard Gittleman, "The Banjul Charter on Human and Peoples' Rights: A Legal Analysis," in Claude E. Welch, Jr., and Ron I. Meltzer, eds., Human Rights and Development in Africa (Albany, N.Y.: State University of New York Press, 1984).

16. The Langi are the ethnic group to which Milton Obote, Amin's predecessor and successor, belongs. For accounts of the slaughter of these and other ethnic groups in Uganda, see Africa Contemporary Record 4 (1971-72), B229, and id. 5-11 (1972-73 to 1978-79), sections on Uganda.

17. Amnesty International, Annual Reports, "Kenya," 1966-67, 1967-68, 1968-69. In February 1970, amnesty was granted to all political offenders in the North-East Province. Africa Contemporary Record 2 (1969-70), B128.

18. Africa Contemporary Record 6 (1973-74), B651; id. 7 (1974-75), B643; id. 8 (1975-76), B696.

19. Id. 3 (1970-71), B415; id. 4 (1971-72), B646. 
guarantee that ethnic slaughter will not occur again in Nigeria, especially if economic conditions continue to worsen. Similarly in Ghana, the Ewe of the Volta Region have long been used as ethnic scapegoats. Some Ewe leaders were sentenced to death for subversion during the Acheampong military regime (1972-79) in Ghana, but the sentences were never carried out. ${ }^{20}$ Nevertheless, rumors of Ewe conspiracies continue to circulate in Ghana in the 1980s.

Despite these examples of severe ethnic conflict, one rarely finds in Africa deliberate wholesale slaughter of ethnic groups (as, for example, the slaughter of American Indians during the period of colonization of North America), nor does one find concerted attempts to eliminate ethnic languages or religious practices. The emphasis on group rights in the African ideal both reinforces the claims of African nation-states vis-à-vis the Westerndominated world economy and encourages the rights of subnational cultural groups within Africa.

Yet the African Rights Charter, like the U.N. standards, is a political document, emanating from the Organization of African Unity, whose Charter has itself been criticized for being little more than a formulation of rights for heads of state. ${ }^{21}$ The African Rights Charter's underplaying of individual rights allows for considerable abuse of those rights enshrined in the Civil-Political Covenant. The question arises, therefore, which ideal is one to choose as a basis for one's measurement of human rights guarantees or abuses? Does one choose the "universal" U.N. package or the "specific" African package? If one opts for specificity of rights, then to what are they specific: to continent, to nation-state, to "race" or ethnic-cultural group? Can generalizations about human rights be made outside of specificities of place, time, and "level of development"?

Academics cannot limit their analyses of human rights to comparisons with international human rights documents. Insofar as all of these documents are essentially political treaties based on compromise and consensus (and indeed, some skeptics would argue, nation-states' guarantees not to rock each others' respective boats), they are neither in the philosophical nor the sociological sense universally valid documents. Similarly, to criticize African or indeed any other national, regional, or continental human rights practices on the bases of these documents is to beg the question of whether human rights are culturally specific as well as the question of whether poor or newly developing countries may be held to the

20. Amnesty International, "Report on the Death Penalty: Ghana" (1979). The Ewe prisoners, sentenced in August 1976, were released in 1978.

21. See Charter of the Organization of African Unity (O.A.U. Charter), adopted 23 May 1963; 479 U.N.T.S. 39 (1963); reprinted in International Legal Materials 2 (1963), 766. Olajide Aluko, "The Organisation of African Unity and Human Rights," The Round Table 283 (July 1981), 240, quotes Kwame Nkrumah as having referred to the O.A.U. as "a trade union of African presidents." 
same standards as wealthy, developed countries. Human rights abuses are not merely the result of lack of political will or selfish unwillingness to give up elite pleasures. Judgments must be historically based, must compare groups at similar levels of social evolution or development, and must take into account different cultural traditions.

\section{COMPARING AFRICA WITH WESTERN DEMOCRACIES}

A second implicit comparison which African and Western scholars make is evaluation of human rights in the Third World against human rights standards in Western democracies. In general, African and other Third World countries fare quite poorly in such comparisons. Western democracies allow high levels of individual civil and political rights, and can afford a high level of social security guarantees of basic economic needs, as well as social and cultural rights.

The evaluation of human rights in Africa in comparison with the U.N. ideal can at least be justified on the ground that the U.N. standards represent a minimum international moral consensus constantly being reevaluated and adjusted as more Third World input into that forum augments understanding of the peculiar constraints of economic underdevelopment and past political colonialism. The U.N. ideal is just that, an ideal toward which Third World nations can strive at a pace which takes into account their problems of development. The Western comparison, on the contrary, is abstracted from both history and economics. It presents as a matter of Western moral commitment and political will what is in fact a matter of enormous economic advantage and centuries of class, ethnic, racial - and now sexual - conflict.

A common means which Third World nations employ to reply to what they rightly consider to be unfair comparisons with Western nations in the area of human rights is to point out the deficiencies in human rights practices which still exist in Western democracies. Underlying these defensive criticisms is a sense of the biases which still exist in the liberal ideal of human rights, even though the original liberal ideal has been supplemented in the last hundred years by a growing quasisocialist sense of the state's moral burden to provide for basic welfare rights for all its citizens. The Western world still stresses the rights of formal political participation and judicial equality, emerging from the French and American revolutions, over the rights of economic equality emerging from Marxism and the Soviet and Chinese revolutions, as well as over the late twentieth-century concern for new "solidarity" rights such as the right to peace and to a healthy environment. It also stresses, again, individual over group rights.

The differences in human rights philosophies of the Third World and the Western world reflect not only differences in ideologies, but also differences in historical experiences and in present forms of social organization. The 
Western stress on individual political liberties and rights under the law emerged from the struggle of the capitalist bourgeoisie to assert its independence against the kings and feudal nobilities of early modern Europe. ${ }^{22}$ The mode of economic organization was individual ownership of land and capital along with private employment of labor alienated from the means of production. By contrast, in most new African states there is either a mixed economy with a procapitalist bent, as in Nigeria; a heavily nationalized statecapitalist economy, as in Zambia; or a protosocialist economy, as in Tanzania.

The demands on these economies are heavy. Rapid decolonization in the 1960s was accompanied by rash promises by the new political elites to grant all of the economic demands which a "revolution of rising expectations" had generated among local populations. The economic expectations of the newly freed masses who were the bases of the new elites' political support combined with the ancient African belief in the moral value of economic redistribution to result in a heavy political stress on the "group right" of economic welfare. Unfortunately, however, the new African governments have neither the economic nor the administrative resources (regardless of political will) to fulfill welfare demands. Basic communication and transportation infrastructures do not exist, nor does a tax base which can support complete social security. Human capital resources are scarce, and the bureaucracy is in its infancy.

What confronts Africa, therefore, is precarious elite rule which can justify itself and maintain itself in power only by fulfilling at least some of the massive demands upon it for economic growth, equitable distribution of wealth, basic welfare servicing, and civil and political freedom; in other words, for the rapid creation of a society which approximates those of the Western world today. But how did the Western world itself achieve its enviable human rights position? If Africa is to achieve what the Western world has achieved, then it must study the methods by which those achievements came about. Perhaps the more realistic comparison to be made, therefore, is that of late twentieth-century Africa with Western Europe at a similar stage of economic and political development.

The major tasks which new African states face are twofold. The first is the political consolidation of a nation-state in the face, especially, of particularistic ethnic loyalties and, in some countries, regional rivalries heightened by inequitable economic development under British rule. In comparisons of African with Western human rights, it is often forgotten that during Europe's own stage of nation-building, massive violations of what we would now consider elementary human rights occurred. In Britain and France, for example, local-language speakers were forced by law and

22. Michael E. Tigar and Madeleine R. Levy, Law and the Rise of Capitalism (New York: Monthly Review Press, 1977). 
violence to adopt the new "national" languages. ${ }^{23}$ Religious wars occurred; Catholic and Protestant states were carved out; and extreme religious deviants such as the Moors in Spain and the ubiquitous Jews were either expelled, confined to ghettoes, or murdered. "National" cultures were, in other words, secured by brute force, in the absence of any moral concern for freedom of speech, religion, or political participation.

By contrast, African states are faced with the task of forging nations out of often recalcitrant local populations while guaranteeing a host of civil and political freedoms which allow for local criticisms, participation, and defense of subnational "group rights." The international and indigenous expectation, moreover, is that this creation of nationhood should be accomplished literally overnight. To function effectively in the modern international economy, Africa must be organized on the basis of definite geographical boundaries; rules of commerce must apply everywhere within each geographic entity; and both foreign visitors and urban administrators expect to find uniformity of laws, language, and customs wherever they go. The task of nationbuilding might be slightly easier in Africa if the boundaries presently being consolidated had emerged from centuries of indigenous political conflict, as they did in Europe; if, for example, the Ashanti had indeed expanded all over Ghana and into Ivory Coast and Togo; if the Kenyan Somalis were actually resident in Somalia; if the Buganda kingdom had expanded and conquered the small ethnic groups surrounding it; if northern, western, and eastern Nigeria had evolved as three different countries. But in Africa, the ruling elites must forge a sense of nationhood out of artificially imposed geographical boundaries while facing human rights constraints and possibilities of international moral censure which were unknown at the time of the European consolidations.

The second problem which African governments face is that they are obliged to implement, as soon as possible, a whole range of "new" rights which were unknown in Europe until the early twentieth century. In the civil and political realm, they were obliged to grant all of the rights which evolved in Europe in the eighteenth and nineteenth centuries, such as the right to an independent judiciary and the right to formal political participation. ${ }^{24}$ But they are also obliged to grant all of the new twentieth-century rights. For example, there is pressure upon them to liberalize a whole host of traditional customs in the direction of individual women's autonomy: ${ }^{25}$ this pressure

23. On France, see Eugen Weber, Peasants into Frenchmen: The Modernization of Rural France, 1870-1914 (Stanford: Stanford University Press, 1976), chap. 6, "A Wealth of Tongues."

24. On the granting of basic civil-political rights in Europe, see Robert Justin Goldstein, "Political Repression and Political Development: The 'Human Rights' Issue in Nineteenth Century Europe," in Richard F. Thomasson, ed., Comparative Social Research, vol. 4 (Greenwich, Conn.: Jai Press, 1981), 161-198.

$: \rightarrow$ Rhoda Howard, "Human Rights and Personal Law: Women in Sub-Saharan Africa," Issue 12 (Spring-Summer 1982), 45-52. 
emanates both from international ideological criticism and from the preferences of urban, westernized elite African women. African governments are also obliged to grant rights to refugees and aliens, even though international obligations toward refugees principally emerged in the period after World War ${ }^{26}$ and even though the refugee burden in Africa is higher than in any other continent. ${ }^{27}$ The African expulsions of ethnic minorities (such as that of the Asians from Uganda and Kenya), or indeed of other African aliens (such as the expulsion of 100,000 people from Ghana in $1970{ }^{28}$ ), and the expulsion of two million people from Nigeria in 1983 parallel European ethnic expulsions of earlier times. Unlike Europe, however, Africa has no colonies to which to send its ethnic minorities or its surplus labor. The insistence on universality of political rights in Africa, a very late development in the Western democracies, constitutes a considerable political cost to the new African nation-states and especially to their new elites.

Finally, African governments have accepted that it is their immediate obligation to institute economic development (loosely comprising absolute economic growth, redistribution of wealth, and increased national autonomy) as soon as possible. They have accepted in principle the entire burden of the welfare society, as defined not only by the Western capitalist world, but more comprehensively by socialist Europe; hence, for example, the right to work, not guaranteed in welfare societies in the West, is guaranteed in some African constitutions. ${ }^{29}$ Such economic obligations were not deemed to be part of the state's duties in Europe until well after national consolidation had taken place and basic civil and political rights had been awarded (to men only) after a long period of class struggle. Moreover, Europe and North America had at their command, when they began to implement welfare policies, the accumulated wealth of four centuries of imperialism and industrialization. With far fewer resources, African governments are attempting to implement much more in the way of economic rights, within a much shorter, indeed a comparatively minuscule, period of time.

A comparison of human rights in Africa in the 1980s with human rights in the Western world at similar stages of national consolidation and

26. See Atle Grahl-Madsen, The Status of Refugees in International Law, vol. 1 (Leyden: A. W. Sijthoff, 1966), 9-27, and vol. 2 (Leyden: A. W. Sijthoff, 1972), 17-23. See also Louise W. Holborn, Refugees: A Problem of Our Time, vols. 1 and 2 (Methuen, N.J.: Scarecrow Press, 1975).

27. Rhoda Howard, "The Canadian Government Response to Africa's Refugee Problem," Canadian Journal of African Studies 15 (1981), 95-116.

28. Margaret Peil, "The Expulsion of West African Aliens," Journal of Modern African Studies 9 (1971), 205-229.

29. The Constitution of Tanzania (1979), "Forward: the Foundations of the Constitution," section C(IV), states that "every community has the duty . . . to ensure that . . every man [sic] able to work does work..." The Constitution of Nigeria (1979), art. 17(3)(a), specifies that all citizens are to have adequate means of livelihood and "adequate opportunities to secure suitable employment." 
economic development is, then, must more appropriate than a comparison of Africa with contemporary Western societies. Such sociologically relevant comparison will reveal the disadvantages under which Africa labors: fewer resources combined with much higher human rights expectations. With such a comparison in mind, we can ask what is reasonable to expect of new African nation-states, rather than merely enumerating the ways in which Africa has failed to live up to universal or Western ideals of human rights.

\section{COMPARISON WITH AFRICA UNDER COLONIAL RULE}

A minor variant of the comparison of African human rights with contemporary Western human rights is the comparison of postcolonial with colonial Africa. The opinion is sometimes expressed that English-speaking Africa was better off, regarding human rights, under British rule than it is under indigenous African rule. This position implicitly reflects a concern for political stability as the overriding priority of human rights.

It is true that, once Africa had been successfully conquered and all resistance overcome, British rule was relatively benign. The history of the conquest itself, however, reveals massive violations of the right to life and liberty. ${ }^{30}$ The British could be quite ruthless in their suppression of even the slightest resistance. For example, Sir Garnet Wolseley, the hero of the 1874 conquest of Ashanti, had the Ashanti capital of Kumasi burned to the ground. ${ }^{31}$ In Kenya, another country taken through active warfare, every person in the market of the village of Muruka was slaughtered in vengeance for the killing of one British soldier in 1902. ${ }^{32}$ Recalcitrant chiefs were routinely exiled (as was the Asantehene, or king, of Ashanti as well as the Kabaka of Buganda) or detained. The Maxim gun was used in Africa as early as the 1890s against indigenous Ugandan and Tanzanian resistance. ${ }^{33}$ That such brutality was not confined merely to the nineteenth-century imperialist phase is evidenced by the massive incarcerations of "Mau Mau" rebels in Kenya in the 1950s and confinement of African women and children to "protective" concentration camps. ${ }^{34}$

Civil and political rights as the contemporary world now defines them were certainly not practiced under colonial rule; indeed, the British resisted the inclusion of a provision in the Civil-Political Covenant obliging them to implement those rights in their colonies. ${ }^{35}$ The practice of preventive deten-

30. Michael Crowder, ed., West African Resistance: The Military Response to Colonial Occupation (London: Hutchinson, 1971), and Henry S. Wilson, The Imperial Experience in Sub-Saharan Africa since 1870 (Minneapolis: University of Minnesota Press, 1977).

31. Crowder, note 30 above, 42 .

32. Ngugi wa Thiong'o, Detained: A Writer's Prison Diary (London: Heinemann, 1981), 35.

33. John Ellis, The Social History of the Machine Gun (New York: Random House, 1975), 88.

34. Ngugi, note 32 above, 49.

35. James Frederick Green, The United Nations and Human Rights (Washington, D.C.: The Brookings Institute, 1956), 55-57. 
tion, now a favorite weapon of African governments against their opponents, is a direct heritage of the colonial era ${ }^{36}$ carried over from British and colonial law into the independence constitutions. ${ }^{37}$ There was no political participation to speak of in colonial Africa. A few African members were allowed into the Legislative Councils of Ghana ${ }^{38}$ and Sierra Leone ${ }^{39}$ as early as the 1920s, but all decisions of such councils could be overridden by the colonial executive and the colonial secretary. In other countries, admission of Africans into legislative councils was delayed until the 1940 s or 1950s. ${ }^{40}$ These African members were appointed, not elected (except for a few municipal seats); thus ordinary Africans had no political rights whatsoever. Nor was there any real independence of the judiciary. The local district commissioner was normally prosecutor, judge, and jury - in short, a benign, patriarchal "great white father." Only in the higher courts and the urban areas was separation of judiciary from the other organs of government established.

In the economic field, the British practiced forced labor until well into the 1920s. ${ }^{41}$ During World War I, West Africans forcibly recruited into the British army's carrier corps died by the thousands from exhaustion, inadequate provisioning, and unhealthy living conditions. ${ }^{42}$ Trade unions were not permitted until the 1920s; and when they did exist, they had very few rights. ${ }^{43}$ In Kenya, hundreds of thousands of Africans were expelled from their land to make way for white settlers, and African peasants were forbidden to grow profitable crops, such as coffee, in competition with the whites. ${ }^{44}$ Generally speaking, the colonial state assumed no obligation for

36. See Ngugi, note 32 above, 44-51, for a discussion of Kenyan resistance leaders detained under British rule. For an autobiographical account by a Kenyan detainee, see Josiah Mwangi Kariuki, "Mau Mau" Detainee (London: Oxford University Press, 1963).

37. See James W. Skelton, Jr., "Standards of Procedural Due Process under International Law vs. Preventive Detention in Selected African States," Houston Journal of International Law 2 (Spring 1980), 314, and "Ghana's Preventive Detention Act," Journal of the International Commission of Jurists 3 (Winter 1961), 71.

38. A. K. P. Kludze, "Ghana [Constitutional History]," in Albert P. Blaustein and Gisbert H. Flanz, eds., Constitutions of the Countries of the World (Dobbs Ferry, N.Y.: Oceana Publications, October 1982), 4.

39. W. S. Marcus Jones and G. F. A. Sawyerr, "Sierra Leone [Constitutional History]," in Blaustein and Flanz, note 38 above (June 1979), 3.

40. For details of each country, see Blaustein and Flanz, note 38 above.

41. On Ghana, see Roger G. Thomas, "Forced Labour in British West Africa: The Case of the Northern Territories of the Gold Coast, 1906-1927," Journal of African History 14 (1973), 79-103; see also the account of forced labor, by A. T. Nzula, I. I. Potekhin, and A. Z. Zusmanovich, Forced Labour in Colonial Africa (London: Zed Press, 1979; originally published 1933).

42. David Killingray and James Matthews, "Beasts of Burden: British West African Carriers in the First World War," Canadian Journal of African Studies 13 (1979), 5-23.

43. See Nzula, Potekhin, and Zusmanovich, note 41 above, 119; see also Sharon Stichter, "The Formation of a Working Class in Kenya," in Richard Sandbrook and Robin Cohen, eds., The Development of an African Working Class (Toronto: University of Toronto Press, 1975), 43-44.

44. E. A. Brett, Colonialism and Underdevelopment in East Africa (London: Heinemann, 1973), 208. 
economic development or economic rights until 1939, when the exigencies of wartime production forced more rational consideration of all British resources. Nor was there any notion that the British should ensure in their colonies even the limited range of social welfare provisions which existed at home.

In the cultural field, the British, perhaps unintentionally, undermined local pride and dignity by the introduction of Christian churches and mission-run schools. There African members of a putative urban elite learned to imitate whites in dress and manner, and to denigrate their own cultural heritage. Cultural diffusion, in which Africans might have made their own choices about which aspects of Western mores they wished to adopt, was accompanied by cultural compulsion; the price of schooling was conversion to Christianity. Newly Westernized "young men" challenged the authority of their elders, while the relatively high status of women in indigenous African societies was eroded by the imposition of Western patriarchal ideals. In defense of the British, it can be said that African languages were not formally abolished, nor were indigenous religions disallowed (except when their provisions, e.g., infanticide of twins or trial by ordeal, were deemed contrary to "natural justice" ${ }^{45}$ ). Yet racial discrimination was commonplace. Indeed, Jomo Kenyatta, then President of Kenya, could still rouse a cheer from the popular masses in the 1970s by explaining that the African elite now owned the best land, shops, and homes, formerly for whites only. ${ }^{46}$

This short description of human rights under British rule serves to illustrate that the colonial power was not concerned to grant to its colonial subjects the rights of citizens in the mother country, even given the limited definition of human rights which prevailed at the time. What the British did do during the colonial period was to eliminate all overt interethnic conflict; to abolish, where it existed, African domestic slavery; and to stop the expansion of African empires. Thus a great deal of political conflict which might have occurred in a noncolonized Africa was deflected, only to emerge, in sometimes more violent form, in the postcolonial period. Although eighteenth- and nineteenth-century Ashanti expansionism seems to have been completely quelled by British rule in Ghana, the smaller ethnic groups' fears of Buganda power in Uganda have been a prime cause of the intense postcolonial civil conflict. In Nigeria, the power of the northern Islamic empires was temporarily checked by British rule, only to emerge after 1960 against the challenge of the new Westernized Igbo with their dominant positions in trade, the professions, and the bureaucracy.

\footnotetext{
45. All Africa Council of Churches, "Factors Responsible for the Violation of Human Rights in Africa, Issues 6 (Winter 1976), 44, and David Westerlund, "Freedom of Religion under Socialist Rule in Tanzania," Journal of Church and State 24 (Winter 1982), 93.

46. "The President's Kenyatta Day Speech: Warning to Opponents" (reported on Radio Nairobi, 20 October 1972), Africa Contemporary Record 5 (1972-73), C128.
} 
To compare human rights in contemporary Africa unfavorably with human rights in the colonial period, therefore, is to concentrate on a very limited range of "rights," namely, peace, relative predictability, and "benign neglect" of indigenous ethnic groupings. In a country as wracked by internal tensions as Uganda has been since 1969, such elementary rights are valued indeed; the British did not murder individuals merely on the basis of their ethnicity, and once their conquest was assured, peace did reign within the narrow confines of paternalistic dictatorship. But were the British still in power today, the narrowness of the range of rights they allowed and planned for would be even more obvious than it was during the nationalist agitation of the 1950s and 1960s. The new states of postcolonial Africa have assumed responsibility for massive development and social welfare programs; programs undreamed of during colonial rule. Their failure to implement these programs causes political unrest which often results in state repression. Such repression may not differ in degree from that practiced by the British, but it does differ in kind. More is expected of independent African governments by way of civil and political rights than was ever expected of the British; thus the independent governments' attacks on those rights appear, to the internal and the international observer, much worse than the British outright denial of them.

\section{COMPARISONS WITH PRECOLONIAL AFRICA}

Several African writers ${ }^{47}$ contend that there is a uniquely African concept of human rights, that is, that concepts of human rights are culturally specific, not universal. Hence the Universal Declaration of Human Rights cannot be applied to the African continent without substantial modification, despite the Organization of African Unity's having endorsed the Declaration and despite the standard list of human rights and fundamental freedoms included in many African constitutions. ${ }^{48}$ To support their contention, these writers refer to a model of precolonial African society which, they maintain, is still the backbone of African ways of thinking and of African social organi-

47. See especially Dunstan M. Wai, "Human Rights in Sub-Saharan Africa," in Adamantia Pollis and Peter Schwab, eds., Human Rights: Cultural and Ideological Perspectives (New York: Praeger, 1979), 116-118; Asmarom Legesse, "Human Rights in African Political Culture," in Kenneth W. Thompson, ed., The Moral Imperatives of Human Rights: A World Survey (Washington, D.C.: University Press of America, 1980), 125-128; and Chris C. Mojekwu, "International Human Rights: The African Perspective," in Jack L. Nelson and Vera M. Green, eds., International Human Rights: Contemporary Issues (Stanfordville, N.Y.: Human Rights Publishing Group, 1980), 85-87. [Editor's note: but see Okere, note 14 above.]

48. E.g., Constitutions of Gambia (1970), Ghana (1979), Kenya (1969), Nigeria (1979), Sierra Leone (1978), Uganda (1967), and Zambia (1973), in Blaustein and Flanz, note 38 above. The Tanzanian (1977) and Malawian (1966) Constitutions do not list fundamental rights and freedoms. 
zation, even in the modernized economic sectors and urban areas. I call this model of precolonial African society the communitarian ideal. ${ }^{49}$

The communitarian ideal asserts that African social organization differed, and still differs, from the Western world in three crucial respects. The first is that people do not think of themselves as individuals, nor do they worry about individual rights; rather, personhood is attained by fulfilling one's role in the community, and people are more concerned with group, especially ethnic-cultural, than with individual rights..$^{50}$ The second respect is that political decisions are made through group consensus, the chief consulting the elders who in turn represent the people; hence the competitive model of party politics is inappropriate and the concept of "loyal opposition" is incomprehensible; all loyal members are part of the group and opponents are by definition not loyal. The final respect in which African social organization differs from the Western is economic: in precolonial and present-day Africa, wealth is automatically redistributed; there is no concept of private property, and the wealthy man is respected only if he shares his good fortune with his kin and coethnics.

It is true that in many of the relatively homogeneous, undifferentiated simple societies of precolonial Africa, both economic and political "rights" were guaranteed, at least at the local level, by communal structures. Obligations to family and kin ensured sharing of resources, however scarce. Land was distributed on the basis of need: even domestic slaves were allocated land to support themselves. Even after a great deal of social change, this pattern of resource distribution and family-based sharing continues in contemporary Africa. Nepotistic corruption and patron-client relations are a form of wealth-sharing; national and local governments' resources are distributed by government or bureaucratic officials along ascriptive kin, ethnic, and language criteria. Wealthier urban migrants remit earnings to their families and invest in self-help projects in rural areas. Redistribution of resources is still a potent social ideal.

Similarly on the civil and political level, many of the nondifferentiated, ethnically homogeneous societies of rural Africa had effective means for guaranteeing what is now known as human rights. In those societies in which centralized state structures had not evolved before European conquest, chiefs were selected by and were accountable to tribal elders; and large, village-level meetings in which free speech was allowed were com-

49. I discuss this ideal thoroughly in Rhoda Howard, "Is There an African Concept of Human Rights?"; Working Paper no. A:8, Development Studies Programme, University of Toronto; also in R. J. Vincent, ed., Human Rights and Sovereignty: Issues and Responses (under review by George Allen and Unwin, London).

50. Ifeanyi A. Menkiti, "Person and Community in African Traditional Thought," in Richard A. Wright, ed., African Philosophy: An Introduction, 2d. ed. (Washington, D.C.: University Press of America, 1979), 157-168. 
monplace. ${ }^{51}$ The courts operated on the basis of common sense morality rather than formal legal procedures; ${ }^{52}$ this was an effective means of regulating social relations in societies in which all individuals were known to the judges and in which the question to be resolved in a trial was normally not whether the accused had committed a crime, but rather what his just punishment should be.

The existence of these indigenous political and legal structures, which do indeed guarantee fair play, is often invoked by African political leaders to justify their own national political practices. For example, Tanzania refers back to the consensual model of politics to justify reliance on political mobilization and discussion within a single political party rather than having a formally competitive multiparty system. Malawi justifies its use of so-called Traditional Courts, which disallow defense attorneys even though the courts exercise the power of capital punishment in murder and treason trials, ${ }^{53}$ by referring back to indigenous models of community-based, relatively informal systems of popular justice. The new Rawlings regime in Ghana (1982- ) uses a similar justification for its new People's Courts ${ }^{54}$ even though some critics maintain that the judges in these new courts are not traditional chiefs and elders, but rather young pro-Rawlings thugs. ${ }^{55}$

Elsewhere I have criticized in some depth ${ }^{56}$ the elevation of Africa's communitarian social structure to a unique ideal of human rights. The communal society does not exist in urban areas and is increasingly breaking down in the rural areas as well, as national political culture evolves and as economic resources, especially land, become more and more scarce. Constant references to communal society can be, and are, used to mask systematic violations of human rights in the interests of ruling elites.

Moreover, the picture of precolonial African social relations on which the communal model is based is inaccurate even regarding the past. Some African societies, such as the Northern Nigerian Emirates and Buganda, were actually powerful empires in which there was social stratification

51. See, for example, the account by K. A. Busia of Ashanti practices, in his Africa in Search of Democracy (New York: Praeger, 1967), 22-30.

52. On traditional African legal systems, see James C. N. Paul, "Human Rights and Legal Development: Observations on Some African Experiences," in James C. Tuttle, ed., International Human Rights Law and Practice (Chicago: American Bar Association, August 1978), 23-37.

53. "Malawi-Criminal Jurisdiction," The Review of the International Commission of Jurists (March 1970), 6-7, and "Malawi," id. (June 1982), 13-14. See also various Amnesty International reports on Malawi, e.g., Amnesty International, Bulletin (Canada) (March 1977).1

54. See West Africa, various 1982 reports, including "People's Court at Work" (18 October 1982), 2703, 2705-06, and "Bar's Boycott [of People's Courts] Bites" (25 October 1982), $2772-75$.

55. Communiqué issued by the Ghana Catholic Bishop's Conference (Wa, Upper Region; 5-10 July 1982), reprinted in The Standard (Accra) (1 August 1982), 4.

56. Howard, note 49 above. 
among nobles, freemen, and slaves and in which political structures were relatively authoritarian. More to the point, the model now applies only to those hinterland parts of African countries which are still relatively unintegrated into the peripheral capitalist economy. National economic policies are based more and more on individual acquisition of wealth; political decisions are made more and more by elites with only ritualistic consultation of the masses; and people think of themselves more and more as individuals with varying wants and needs, not merely as members of their natal ethnic groups or villages.

Some African scholars present the communitarian ideal as a model of social relations which is specifically African in content; thus they argue for cultural specificity on a racial or regional basis. In fact, however, the model is not confined to Africa; rather, it represents typical agrarian, precapitalist social relations in nonstate societies. It would be useful, for example, to compare such African societies with preindustrial England. Undoubtedly, in the closed-village societies of premodern Europe, we would also discover that people thought of themselves more as members of their own local groups than as individuals, finding a sense of identity by fulfilling their assigned roles rather than by fulfilling "themselves." A counterpoint to the feeling of belongingness would be hostility to strangers, such as outside traders or Jews, just as it is in African societies with their "Zongos," or strangers' quarters. In the feudal system, the lords took some responsibility for storage of grain and protection from famine, just as the chiefs were responsible for redistributing food and allocating land in precolonial Africa.

I do not wish to stretch the comparison too far: feudal Europe and precolonial Africa are not altogether analagous. The point, however, is that both were relatively simple social structures. What some writers view as essentially different African and Western social structures and ways of thinking are actually differences between relatively simple and relatively complex societies. ${ }^{57}$ In simple societies, there is little social stratification, so that it is easy to have consensual decision-making and redistribution of wealth; there are no economic classes competing against each other for scarce resources. Moreover, social roles are undifferentiated; the villager who fulfills his role as husband is also fulfilling his role as farmer and as respected man in the community. But in more complex societies the roles of husband, economic man, and political man are differentiated; and the individual is likely to compartmentalize himself, having different associational ties for each role. Thus in politics he has more than one interest and cannot easily rely on a community leader to express all his interests for him. Finally, in more complex societies, the different functions of authority, such as law, government,

57. The sociological originator of the distinction between simple and complex societies is Emile Durkheim, The Division of Labour in Society (New York: The Free Press, 1933; 1st ed. 1893). 
police, defense, administration, education, and social welfare, are compartmentalized and bureaucratized. The individual is confronted with new organizations operating by impersonal rule, not by friendly personal contact. His own life becomes compartmentalized insofar as he must deal with different institutions for different aspects of his needs and wants. Modern man, then, becomes individualized, fragmented, and cut off from community ties. ${ }^{58}$

Thus comparison with precolonial Africa is of limited use, if any, insofar as it purports to provide us with an alternative, culturally specific model of human rights indigenous to Africa or Africans. It is useful, however, as a reminder of the kind of society in which many rural Africans still live, despite the increasing institutional ubiquity of the centralized modern state and of the kind of society in which many urban and rural elite Africans still have very real roots. The elite spokesperson who maintains that Africans are not so competitive, profit-seeking, and individualistic as North Americans may be correct, not because Africans are African but because their social organization is still less complex and less institutionally differentiated than that of the Western industrial world. To base human rights policy on this model of rural Africa, however, is to ignore the changes which have occurred and are occurring in the way Africans live, in particular how their lives are affected by all those institutions that the state controls. Under such new social conditions, new methods of guaranteeing human rights become essential. Comparison with precolonial society is useful insofar as it explains the cultural and psychological roots of modern African man, but it is not useful if it is taken as a factual description of contemporary African social organization.

\section{CONCLUSION}

I began this article by suggesting that commentators on human rights in Africa, or indeed anywhere in the world, need to be aware of the implicit comparisons they make regarding guarantees, implementations, and abuses of human rights. It is important to be aware and critical of one's implicit comparisons.

The use of comparisons themselves, however, is not only a legitimate but indeed, I would contend, a necessary part of analyzing human rights. Ultimately, human rights practices are based not in law or philosophy, but in real social relations. Such social relations vary across time and place, across history and culture. By looking at human rights in a comparative framework, one can obtain a sense of how human rights practices can or may change: one can predict what human rights violations may be remedied or may arise,

58. See Peter Berger, Brigitte Berger, and Hansfried Kellner, The Homeless Mind: Modernization and Consciousness (New York: Vintage Books, 1973). 
rather than merely engage in static description or in post hoc analysis. Comparisons ought to be historical, not merely in a temporal but, more importantly, in a social sense. Social chronology implies comparing societies at similar stages of development. This does not mean that one ought to be an evolutionist, assuming that all societies evolve through exactly the same stages in an orderly, and inevitable, progression. It does mean that one ought to try to compare societies with similar levels of wealth or in similar stages of economic development, taking into account also similarities in the level of national consolidation and institution-building.

An historical sense also means that one will be aware that no society is static. The harkening back to precolonial Africa that is typical of a number of Africans commenting on human rights in their own continent implies an essentially ahistorical approach. All societies change. Africa, as a result of five centuries of incorporation into the world economy and one century of colonial conquest and control, has changed more than most. To present a static picture of communal relations which may have existed in some parts of Africa before contact with Europe began, as a model for contemporary human rights in Africa, is to deny history completely.

Historical comparisons must be combined with a sense of social structure. Whether one compares societies at the same or different times, one is comparing social structures. Contentions that human rights beliefs are specific to particular places (the West, Africa) should not be interpreted as evidence of differing racial or geographical philosophies. Rather, they represent the reflection of different social structures in different belief systems. Although parallels between different social entities can never be exact, we can find substantial similarities in human rights beliefs and practices in the simple, nondifferentiated societies of premodern Europe and precolonial Africa. The communal model of social relations, insofar as it actually exists, is not unique to Africa.

In insisting on the necessity of historically and structurally accurate comparisons, however, I do not mean to deny the independent role of ideas and ideals in shaping any society's view of human rights. People can and do act independently of history. Any prediction based on social scientific analysis can fall flat because of how people act, and how people act is often determined by the ideas they hold dear, even when those ideas may seem inappropriate, in a scientific sense, to their time and place. In Africa the independent role of ideas is more obvious than in Europe. Whereas Europe has been an originator of modern ideologies, Africa has been to a large extent a (sometimes unwilling) recipient. African politicians, philosophers, and lawyers have all been influenced by the Christian religion and by liberal political and judicial ideals which the British introduced into their colonies, even when the British practice fell far short of Britain's own ideals. In more recent times, African intellectuals and other members of the elite have been influenced by both the socialist view of human rights and the emerging inter- 
national consensus on human rights reflected in the various U.N. standards as well as in Africa's own Rights Charter. Ideas, transformed into fact by human actors endowed with free will, can challenge and overcome both structural constraints and historical "inevitability."

Individuals are not, of course, mere agents of history or victims of social structure, nor are they mere implementers of ideas. Individuals are also selfish human beings, who normally act in a rational manner calculated to achieve their own self-interest. In some societies, including many in precolonial Africa, an individual's self-interest is perceived to be best guaranteed by conformity to group norms and by acting in concern with the group. But in contemporary Africa, in rural as well as urban areas, it is increasingly the case that the individual both separates himself from the group and can no longer rely on a particular group leader to represent him in the multiplicity of his relations with the modern economy and the new state structure. He then begins to represent himself in the new competitive economic and political marketplace. Inevitably, a few individuals rise to the top in this new competitive society.

In Africa, as elsewhere, therefore, new elites are forming as hundreds of millions of individuals pursue their own self-interest. There is nothing new or surprising about this; all historical and structural comparisons will lead to the conclusion that in all but the most primitive of societies, social stratification occurs and elites dominate. In the African as in all other contexts, the existence of elites implies the possibility of elite manipulations of human rights in their own interests. Such elites may enunciate a specifically "African" theory of human rights merely as a legitimizing ideology, ${ }^{59}$ a cover for their own interests. Thus, for example, the denial of a concept of loyal opposition in African cultural history can become an excuse for holding political dissidents in preventive detention.

The use of historical and structural comparisons can assist the analyst in separating what is actually possible from what is merely the ideal in the practice of human rights. This is an important distinction to make, especially in newly independent, poor countries such as English-speaking sub-Saharan Africa. But men make history, and elites can control men. Scientific comparisons may be used as explanations, but should never be used as excuses, for human rights abuses. The Nigerian writer Wole Soyinka speaks of "power morality." 60 Power morality is undoubtedly the most enduring enemy of real human rights, in Africa as elsewhere.

59. Claude Ake, A Political Economy of Africa (Harlow: Longman, 1981), 180.

60. Wole Soyinka, The Man Died (New York: Harper and Row, 1972), 90. 